\title{
Evolution of education: From weak signals to rich imaginaries of educational futures
}

Gidley, Jennifer

https://researchrepository.rmit.edu.au/esploro/outputs/9921858152401341/filesAndLinks?institution=61RMIT_INST\&index=null

Gidley, J. (2011). Evolution of education: From weak signals to rich imaginaries of educational futures.

Futures: The Journal of Policy, Planning and Futures Studies, 44(1), 46-54.

https://doi.org/10.1016/j.futures.2011.08.006

Document Version: Accepted Manuscript

Published Version: https://doi.org/10.1016/j.futures.2011.08.006

Repository homepage: https://researchrepository.rmit.edu.au

(c) 2011 Elsevier Ltd. All rights reserved

Downloaded On 2023/04/26 20:58:06 +1000 


\title{
Evolution of Education: From Weak Signals to Rich Imaginaries of Educational Futures
}

\author{
Jennifer M. Gidley \\ Global Cities Research Institute \\ RMIT University, Melbourne \\ Email: j.gidley@planetaryfutures.com.au
}

\begin{abstract}
This paper proposes that all aspects of educational futures are affected by the new thinking patterns and ways of knowing that have been emerging over the last hundred years as part of the parallel processes of evolution of human consciousness and major global societal change. Throughout the $20^{\text {th }}$ century, significant developments can be mapped in most, if not all, of the major academic disciplines. Secondly, the move to transcend disciplinary specialisation, via inter-, multi-, and trans-disciplinary approaches is strengthening. Thirdly, at a higher order theoretical level, these developments are explicitly theorized in the discourses associated with postformal reasoning, integral theory and planetary consciousness. In spite of all these developments in other disciplines and knowledge fields, the institution of mass public education, with its underpinning industrial worldview, has been pretty static since its inception two hundred years ago. Finally, the paper identifies three minor, but significant, waves of evolutionary emergence in education over the last hundred years that if articulated and nurtured could strengthen the development of evolutionary pedagogies for the $21^{\text {st }}$ century.
\end{abstract}

\section{Keywords}

Evolution of consciousness, integral, postformal, planetary, foresight, futures studies, postformal pedagogies, evolutionary pedagogies 


\section{Introduction to Postformal Pedagogies}

This paper sets a broad panoramic scene for futures of education, by obliquely pointing to new developments in other fields. As noted in the introduction to the special issues the discourse on futures of education includes theoretical, practical and speculative research into new paradigm educational models and approaches, many of which have foresight/ futures thinking as part of their underlying worldview.

In my view it is important that the various approaches to educational futures take into account the new thinking patterns and ways of knowing that have been emerging since the early $20^{\text {th }}$ century. In this paper, I contextualise these changes within the parallel processes of evolution of human consciousness and major global societal change. The paper also proposes that these changes, which have been affecting all disciplines and fields of knowledge, require that education begin to embrace what I am calling evolutionary-or postformal-pedagogies.

\section{Evolution of an Educator: A Brief Personal Narrative}

My first involvement with what I call evolutionary pedagogies - or postformal pedagogies - was over thirty years ago when I first encountered Rudolf Steiner's futuresoriented writings on education. The 1970s were exciting times intellectually and culturally as there was an influx of new ideas and cultural movements. As a young psychologist-educator I was influenced by humanist and transpersonal psychology and critical pedagogy theories, e.g., Paolo Freire [3] and Ivan Illich [4]. I was also drawn to various postmodern and feminist philosophers, such as Nietzsche, Foucault and de Beauvoir. There was a powerful shift of consciousness beginning to break into the formal academic world from the periphery at this time. My professional work in educational psychology already focused on the marginal voices. I worked with teachers of young people who did not "fit into" mainstream education, and ran a women's community learning centre empowering "house-bound" women to take charge of their personal futures by re-entering employment and/or tertiary education.

As a professional psychologist-educator, I was aware of serious limitations of the factorylike model of mainstream education and, as a mother, did not consider it suitable for my children. I decided to found a Steiner school, but sought to transcend the conservative, cobweb-covered, 19th century version of Steiner education [5]. The school I founded and pioneered for ten years was a contemporary, creative interpretation of Steiner's pedagogical writings [6-10] adapted to late 20th century, sub-tropical, rural Australia. I became aware intuitively and experientially of what a powerful and positive educational approach this is but was frustrated to realise that it is completely marginalised by academics and mainstream educators alike.

In the 1990s I decided to re-enter the academy, with the aim of both testing my intuitions and finding appropriate language to create dialogue between Steiner's evolutionary pedagogy and the academy. My Masters research indicated that Steiner-educated students, while holding similar fears and concerns about the future to other students, had a stronger sense of empowerment and greater capacity to envisage positive preferred futures [11]. Over the next ten years I continued to broaden and deepen my reading, researching and writing about educational and youth futures $[1,2,12,13]$, post-colonial alternatives to the factory model of schooling [14], the impact of globalisation on young people $[15,16]$, and the evolution of culture and consciousness [17-19].

Around 2000, I (re)discovered Ken Wilber's writing [20-26] and found that it really resonated with my internalised Steiner philosophy. The more I read of Wilber the more I was amazed by the similarity between Wilber's ideas and what Steiner was writing a century earlier. I was surprised that in spite of Wilber's claims to be creating an "integral theory of everything" he had pretty much ignored one of the most integral figures of the 20th century - 
Rudolf Steiner. I undertook doctoral research on the relationships between their works. But as I began to follow-up on some of the sources that Wilber referred to, such as Gebser [27] and Sri Aurobindo [28], I became drawn into their original writings as well.

As I began to search the literature for others who may have brought these pioneers together academically, I realised that apart from Roland Benedikter's research on Steiner and Wilber [29] (most of which is in German) no one else had undertaken any major research project that incorporated Steiner's, Gebser's and Wilber's futures-oriented, integral contributions.

\section{Evolution of Consciousness as Megatrends of the Mind}

Over the last few years numerous scholars and thinkers from many fields (including complexity science, ecology, education, futures studies, integral studies, philosophy, psychology, spirituality studies and systems theory) have been claiming that the fragmented, mechanistic and materialistic ways of thinking of the last century are no longer sustainable. As Einstein ${ }^{i}$ put it a century ago, "the significant problems we have cannot be solved at the same level of thinking with which we created them."

Furthermore, research on the evolution of consciousness, which was pioneered by Rudolf Steiner in the early $20^{\text {th }}$ century [30], has increasingly gathered impetus throughout the $20^{\text {th }}$ century - particularly among integral theorists [31-39]. These theories are still marginalised by narrow Darwinian notions of biological evolution in spite of significant contestation [40, 41]. I have also noted elsewhere that in addition to the various integral approaches, there is evidence to support the evolution of consciousness from the adult developmental psychology research on postformal reasoning [42-50], and also from the eco-philosophical literature on planetary consciousness [33, 35, 37, 51-57].

My own research over the last decade on the evolution of consciousness has strengthened my intuition that education urgently needs to evolve. Throughout the $20^{\text {th }}$ century, significant developments can be mapped in most, if not all, of the major academic disciplines; and secondly, in relation to the transcending of disciplinary specialisation, via inter-, multi-, and trans-disciplinary approaches. These developments can be regarded as enactments of new ways of thinking and new knowledge patterns, respectively. These new patterns of thinking are arguably facets of the evolution of consciousness. An environmental scan of the major fields of knowledge identifies the following developments:

- The scientific turn from classical physics to quantum physics followed by the shift from the closed systems of classical physics to the open systems of post-classical biology [58], chaos and complexity sciences and emergentism [59-61];

- The eclipsing of correspondence theories of knowledge, such as empiricism, by coherence theories based on social constructivism [62];

- The parallel - though marginalised - philosophical turn from static mechanistic metaphors to organic, living, process metaphors of thinking [63-66];

- The emergence of systemic, holistic and integral thinking in various fields including philosophy [17, 24, 29, 67-69];

- The increasing focus on language as philosophical content - the linguistic turn - and the awareness of linguistic reflexivity in the contributions of the French poststructuralists [70-74];

- An increasing awareness of the politics of discourse and social relations [75-78];

- A renewed awareness of context and historicity through developments in hermeneutics, particularly in Europe [78-83];

- The implications of the information age, particularly the mass media and the world wide web [31, 84]; 
- The movement in political science from the centrality of nation-states to the "rise of the global imaginary" [85] and the more fused, hybrid concepts of global/local, glocal and even "glonacal" [86];

- New attempts to create knowledge-bridges between disciplines, through interdisciplinary and transdisciplinary research [56, 87-90];

- The religious turn in continental philosophy [91, 92] and the spiritual turn in the late works of the French postmodern philosophers [29, 93];

- The transition from studying the past to an awareness of the value of foresight and futures thinking, in parallel, paradoxically, with the deconstruction of the modernist, linear narrative of time.

At a higher order theoretical level, these developments are explicitly theorized and can be meta-cohered using the terms postformal, integral and planetary [19]. These three major strands of research - postformal, integral and planetary - each have a stronger emphasis in a particular area. The postformal psychology literature tends to focus on empirical and analytic articulation of higher stages of reasoning; the integral literature tends to emphasise the epistemological crisis and to promote integral thinking; the planetary consciousness literature tends to emphasise the urgency of transnational collaboration around our planetary crises: ecological, politico-economic and socio-cultural. While it is beyond the scope of this paper to discuss these developments in detail, some key features of the higher stages of reasoning - as identified by adult developmental psychologists and integral theorists-include: complexity, creativity, dialectics, dialogue, futures awareness, holism, imagination, paradox, planetary consciousness, pluralism, reflexivity, spirituality, values and wisdom. These have been discussed in more detail elsewhere [19, 94].

The research in all of these areas has increased dramatically in the last 40 years, and more so in the last decade. These developments have been referred to elsewhere as the "megatrends of the mind" [94]. They have very significant implications for education. My research creates conceptual links between all these changes and the need for the transition from formal, factory-model schooling and university education to a plurality of postformal—or evolutionary-pedagogies [95]. To emphasise my key point, it does not make any sense to educate in the $21^{\text {st }}$ century for $19^{\text {th }}$ century mindsets.

\section{Educational Implications of Megatrends of the Mind}

In spite of all these developments in other disciplines and knowledge fields, the institution of mass public education has been pretty static since its inception two hundred years ago. If education as a whole is to become responsive to the significant implications of the evolution of consciousness the factors that need to be considered include geographic, developmental, historical and cultural aspects of education.

In terms of geography, I have not studied education in non-western geographies in any depth, so my comments are primarily in reference to European developments, which have been picked up in the Anglo-speaking world. These developments have subsequently influenced the current globalising agenda to introduce what I call the "factory model of education" to the rest of the world, particularly via the World Bank's "Education for All" agenda [14].

In relation to levels of education most of my research has been related to school education although the evolutionary imperative also applies to higher education as I have also indicated $[17,96,97]$. I will not discuss this here as it is particularly complex when one begins to take into account Indian, Chinese, Arab/Islamic and other streams of higher education - all of which arguably preceded the European academies and universities. 
In terms of historical perspectives on school education, I have identified three broad phases: i) "informal education" via family/tribal enculturation, elite tutoring, and private religious schooling, prior to the beginnings of mass public education approximately two hundred years ago; ii) "formal school education," from late $18^{\text {th }}$ to $20^{\text {th }}$ centuries in Europe, USA and increasingly in other parts of the world last century; and iii) a diversity of postformal pedagogies, beginning in the late 20th century and-one would hope-flourishing throughout the 21 st century and beyond (See Table 1). This table refers primarily to the situation in the so-called developed world. The situation is far more diverse and complex in traditional, and non Western-European-based cultures.

Table 1: Socio-Cultural, Political and Educational Phases

\begin{tabular}{|c|c|c|c|}
\hline & $\begin{array}{l}\text { Prehistory to } 18^{\text {th }} \\
\text { Century }\end{array}$ & $\begin{array}{l}18^{\text {th }} \text { to } 20^{\text {th }} \\
\text { Century }\end{array}$ & $\begin{array}{l}20^{\text {th }} \text { to } 21^{\text {st }} \text { Century and } \\
\text { Beyond }\end{array}$ \\
\hline $\begin{array}{l}\text { Socio-Cultural } \\
\text { Phases }\end{array}$ & Pre-modern & Modern & Post-modern \\
\hline $\begin{array}{l}\text { Political } \\
\text { Phases }\end{array}$ & City-states & Nation-states & Global-planetary \\
\hline $\begin{array}{l}\text { Educational } \\
\text { Phases }\end{array}$ & $\begin{array}{l}\text { Informal family/tribal } \\
\text { enculturation, } \\
\text { or elite tutoring }\end{array}$ & $\begin{array}{l}\text { Formal schooling, } \\
\text { mass education, } \\
\text { factory-model }\end{array}$ & $\begin{array}{l}\text { Pluralism of postformal } \\
\text { pedagogies, integral, } \\
\text { planetary sensibility }\end{array}$ \\
\hline
\end{tabular}

Prior to the Industrial Revolution, which embedded modernist ideas into the socio-cultural fabric of Western society, education for children was not such a formal process, even in the Western world. Children were enculturated by their extended families and cultures and only the children of the wealthy - who could afford private tutors - or who wished to become clerics, had any formal education. Earlier integrally-inspired educational reform had been initiated in the $17^{\text {th }}$ century by Moravian educational theorist Johann Ámos Komenský (more frequently called by his Latin name Comenius) who wrote the influential Didactica Magna, which proposed a three tier universal schooling system for all children [98]. Subsequently in Germany, the notion of the evolution of consciousness, which was a major contribution of German idealists and romantics such as Goethe, Hegel, Schelling and Novalis, contributed to the initial impulse for mass public school education, which began in Germany in the late 18th century. This was carried forward particularly through Schiller's aesthetic educational principles [99], Herbart's integrative pedagogical system [100] and Humboldt's implementation of public education [101]. However, after the deaths of these leading German philosophers, by the middle of the 19th century the idealist-romantic educational project was largely hijacked in western Europe by the gradual influence of the British Industrial Revolution, so that schools increasingly became training grounds to provide fodder for the factories. This factory model of school education was picked up in the USA around one hundred and fifty years ago [102].

I have begun to use the phrase "evolutionary pedagogies" as an alternative to "educational reform" or even "educational transformation." This is because I want to highlight the scope of the transition we, as humans in a planetary age, are undergoing. The notion of "educational reform" very often only tinkers at the surface of appearances - a bit like rearranging the deckchairs on the Titanic. While the notion of "educational transformation" potentially goes 
further than "reform," it can be limited by the philosophical perspective, ideology—or even paradigm - that it subscribes to. The meaning that I ascribe to my notion of evolutionary pedagogies is one that connects education more consciously with the evolution of new patterns of thinking that appeared in so many disciplines and fields throughout the $20^{\text {th }}$ and into the $21^{\text {st }}$ century.

Fourthly, it may also be helpful to view education in its broader cultural context, as only one of the types of enculturation that cultures provide for their young people. I have recently begun to look at the evolution of education in the context of Foucault's archaeological concepts of connaissance in relation to the institution of education, and savoir for the broader cultural context or worldview [103]. This gives me some hope as I believe it is inevitable that the institution of education-schools, colleges and universities - will evolve as the cultural milieu evolves. This is why I have shifted the emphasis of my own thinking and research, from my earlier focus on educational futures per se, to my current broader focus on futures of culture and consciousness. My understanding of the situation is that there will be no substantial change to the system and institution of education without a change to the way we think and view the world. That is why I have taken such an interest in creating conceptual bridges between the evolution of consciousness discourse, particularly the integral evolutionary views of Steiner, Gebser and Wilber, and the education discourse.

I have scanned the Anglophone educational literature for signs of emerging pedagogies that are reflecting one or more of the features of postformal, integral or planetary consciousness. There is a lot of encouraging material being written about new educational approaches in the last decade. There is also a very powerful neo-fundamentalist backlash in the Anglo countries from government-backed educrats who seek to dominate the educational agenda with scientism, economism and technicism - through the "audit culture" [104]. On the other hand there are also several educational theorists and researchers who are attempting to expose and counter this reactionary neo-conservatism [104-107].

\section{The Evolutionary Waves in $20^{\text {th }}$ to $21^{\text {st }}$ Century Education}

I propose that there have been three waves of educational impulses since the beginning of the $20^{\text {th }}$ century that have contributed to the evolution of education.

\subsection{First Wave: Weak Signals from the Early $20^{\text {th }}$ Century}

Although much of European and Anglo education did lose its initial idealist/romantic impulse during the 19th century, and succumbed to the weight of industrialism, secularism, and materialism, new threads began to emerge in various parts of the world in the early 20th century. There were Maria Montessori and Rudolf Steiner in continental Europe, Alfred North Whitehead in the UK, John Dewey in the USA and Sri Aurobindo in India all pioneeering more integral, organic educational approaches that provided a counter-weight to the dominant factory model. They emphasised imagination, aesthetics, organic thinking, practical engagement, creativity, spirituality, and other features that reflect the emergent integral consciousness. These educational pioneers were also futures-oriented in that they all subscribed in some way to evolutionary notions of consciousness, culture and even cosmos. However, these approaches have mostly remained marginalised, or in the case of Dewey's initiative, been appropriated in a reduced form by the mainstream system as so called "progressive education."

\subsection{Second Wave: "Alternative" Education as a Trend by the 1970s}


What I call the second wave was sparked by the dramatic consciousness changes that erupted in 1968 with the student protests in Paris, followed rapidly by the 1969 Woodstock Peace Festival in the USA, which laid foundations for a youth peace movement against the Vietnam War. These events also paralleled the arrival of futures studies on the academic scene with the journal Futures being founded in 1968 along with significant global meetings such as Mankind 2000 that led to the forming of the World Futures Studies Federation (WFSF). These events coincided with the beginning of various "new age" movements, including participatory politics, new forms of music, east-west spiritual-philosophical dialogues, new gender relations, post-nuclear family lifestyles and recreational use of "designer" drugs. These movements were taken up quite strongly in the Anglo countries, particularly in pockets of the USA and, at least indirectly, began to shift ideas about formal education. The 1970s to 1990s saw a broadening of alternative educational modes, including home-schooling [108], holistic education [109-111], critical pedagogy [3,4], futures education [112-116], and a raft of educational reforms within mainstream settings. All were critical of the formal, modernist 'factory-model' of mass education. Most sought to broaden education beyond the simple information-processing model based on a mechanistic view of the human being to a more holistic, creative, multifaceted, embodied and participatory approach. Yet not all honour the spiritual needs or the multi-layered nature of the developing child, as part of a consciously evolving human species. Furthermore, these approaches are still minor threads and unfortunately most approaches are also isolationist in relation to each other.

\subsection{Third Wave: Rich Imaginaries of Educational Futures for the $21^{\text {st }}$ Century}

What I would call third wave approaches to evolving education are reflected in the plethora of new postformal — or evolutionary_pedagogies, which have emerged, particularly over the last decade. I have identified over a dozen emerging pedagogical approaches that in some way, either directly or indirectly, facilitate the evolution of postformal-integral-planetary consciousness. I have begun the process of hermeneutic dialogue among them, but of course much more research needs to be done. I have broadly clustered them as follows:

- Aesthetic and artistic education [105, 117-119];

- Complexity in education [120, 121];

- Creativity in education [122-127];

- Critical and postcolonial pedagogies [3, 128-130]

- Ecological education and sustainability [116, 131, 132];

- Futures and foresight education [2, 133-135];

- Holistic education [109, 111, 136-140];

- Imaginative education [122-127];

- Integral education [141-143];

- Planetary/global education [12, 15, 121, 144-146];

- Postformality in education [42, 147, 148];

- Postmodern and poststructuralist pedagogies [105, 127, 149-151];

- Social and emotional education [152];

- Spirituality in education [153-157];

- Transformative and contemplative education [36, 158];

- Wisdom in education [50, 137, 159-161]

I have explored this literature in detail elsewhere, including how these new pedagogies intersect with four themes that I identified in the evolution of consciousness discourse [95]. (See Figure 1) 


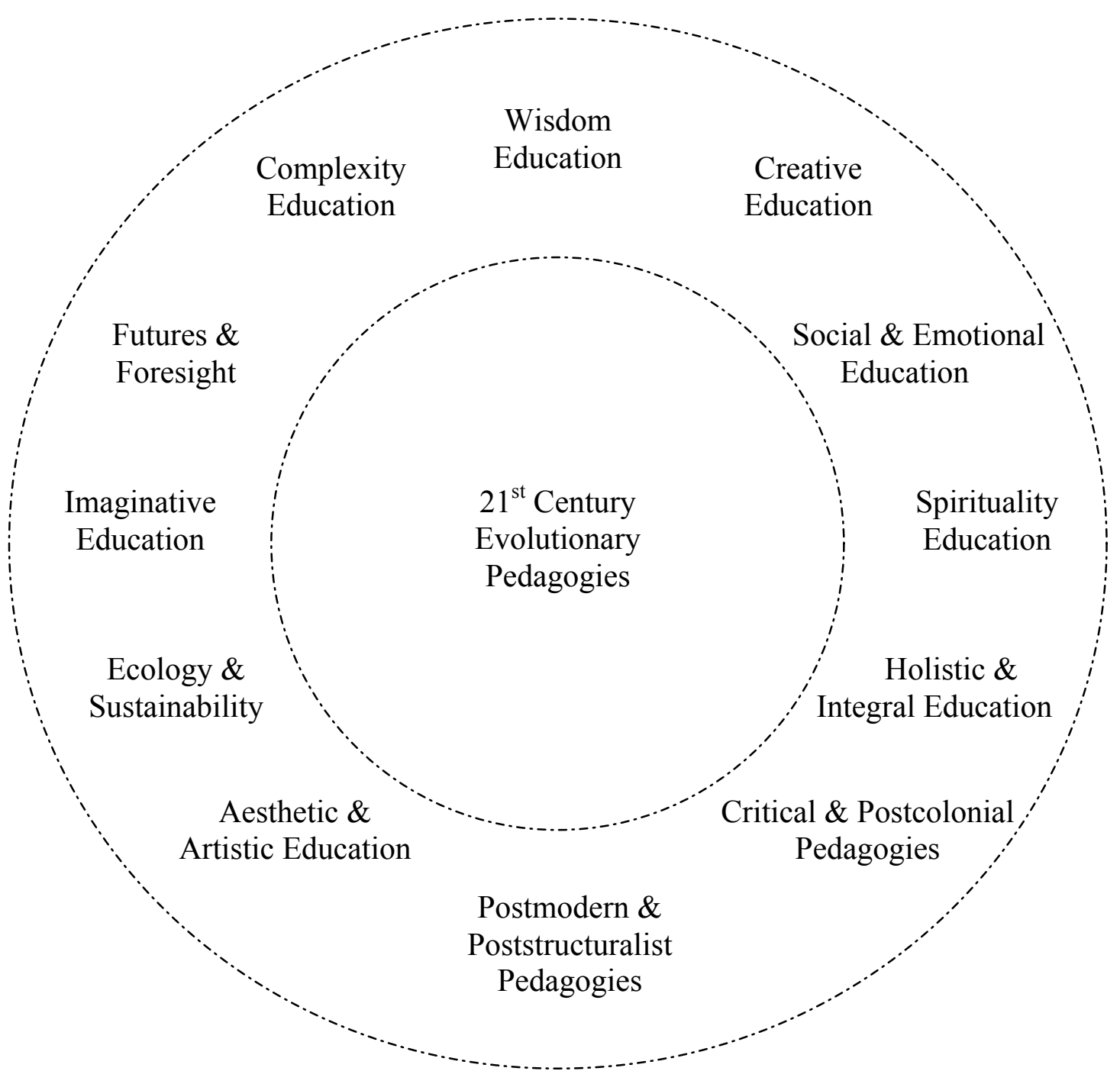

Figure 1: A Clustering of Evolutionary Pedagogies - Adapted from Gidley [95]

Some of these - such as integral education - aim to, or claim to, integrate all previous approaches. There are two major approaches that are identified as integral education in North America - integral education based on Sri Aurobindo's early 20th century philosophy ${ }^{\text {ii }}$ and integral education based on Ken Wilber's AQAL ${ }^{\text {iii }}$ framework. I have identified and analysed a third major integral education approach: Steiner-Waldorf education [18]. The emphasis in Steiner pedagogy on integrating thinking/head, feeling/heart and willing/hands is significantly aligned to Sri Aurobindo's integration of the three yogas of knowledge, love and action [162]. It is important that futures-oriented educators give serious consideration to these and other existing approaches.

In my view, an authentically futures-oriented education would embrace the rich diversity of postformal, integral and planetary pedagogical approaches that are out there, globally, in view of the critical planetary times. Only by enacting conversations among the rich pluralism of evolutionary pedagogies will we begin to have an adequate picture of the rich tapestry of evolutionary change that is already happening before our very eyes. 


\section{Concluding Reflections}

There is a danger, however, in creating a polarising narrative between the mainstream model of education - which is anyway full of particularities - and the kind of evolutionary pedagogies discussed here. There is no doubt that the model of mass public school education that developed during the industrial era has delivered many benefits in the past both for individuals and for society. There is no question that there have been enormous social benefits for multitudes of young people who would not have had access to any formal education in the pre-modern era where school education was only available to the elite. On the other hand the psycho-social pressure on many young people of such processes as high stakes testing has been well-documented. My intention in using the metaphor of "factory" in relation to schooling is to highlight the industrial era underpinning of the schooling model that has become the myth-of-the-given, in order to beg the question of its appropriateness in a postindustrial, planetary era. In a post-Newtonian, post-mechanistic, post-industrial integral age what new metaphors may be more suitable? The university in a garden model perhaps? The forest school model? The learning network model? Or even the extended family model? Futures educators need to think very carefully and creatively about the deep metaphors that underlie how we think about education. But this would be the subject of another paper.

On the other hand if by the traditional model we mean the original model of universal and free public education proposed by Comenius in the $17^{\text {th }}$ century and initiated by Humboldt in Germany two hundred years ago, then I think there is a lot to be gained from a careful historical study of this early pedagogy. After all, this model was first inspired by the unitive spiritual humanism of Comenius and later by the German idealist and romantic philosophers who were far more humanistic than many of the educrats who have been writing national curricula in the world for the past hundred years. Some of the original inspirations included the head, heart and hands approach of Pestalozzi, the integrative interdisciplinary pedagogy of Herbart, the aesthetic educational approach of Schiller and the future orientation of Novalis.

My primary interest in this paper has been to identify and cohere what Nicolescu calls the "luxuriance of the plural" when it comes to futures-oriented educational approaches. By bringing them into relationship with each other we enable a unitas multiplex of postformalintegral-planetary approaches that can learn from each other, inspire each other and give strength to each other. This is what evolutionary pedagogies mean to me.

\section{References}

[1] J. Gidley, S. Inayatullah, Youth Futures: Comparative Research and Transformative Visions, Praeger, Westport, CT, 2002.

[2] J. Gidley, D. Bateman, C. Smith, Futures in Education: Principles, Practice and Potential, Australian Foresight Institute, Melbourne, 2004.

[3] P. Freire, Pedagogy of the Oppressed, Herder and Herder, New York, 1970.

[4] I. Illich, Deschooling Society, Calder and Boyers, London, 1975.

[5] J. Gidley, Beyond homogenisation of global education: Do alternative pedagogies such as Steiner Education have anything to offer and emergent global/ising world?, in: S. Inayatullah, M. Bussey, I. Milojevic (Eds.), Alternative Educational Futures: Pedagogies for Emergent Worlds, Sense Publishers, Rotterdam, Netherlands, 2008.

[6] R. Steiner, The Education of the Child in the light of anthroposophy (GA 34) (2nd ed.) (G. \& M. Adams, Trans.) (Original work published 1909), Rudolf Steiner Press, London, $1909 / 1965$.

[7] R. Steiner, The Younger Generation: Education and Spiritual Impulses in the 20th Century (GA 217) (R. M. Querido, Trans.) [13 Lectures Stuttgart, October 3 to 15, 1922], Anthroposophic Press, New York, 1967. 
[8] R. Steiner, Human Values in Education, Lectures, 1924, Rudolf Steiner Press, London, 1971.

[9] R. Steiner, The Renewal of Education through the Science of the Spirit: Lectures, 1920, Kolisko Archive, Sussex, 1981.

[10] R. Steiner, The Kingdom of Childhood: Lectures, 1924, Anthroposophic Press, New York, 1982.

[11] J. Gidley, Prospective Youth Visions through Imaginative Education, Futures: The journal of policy, planning and futures studies, 30 (1998) 395-408.

[12] S. Inayatullah, J. Gidley, The University in Transformation: Global Perspectives on the Futures of the University, in, Bergin and Garvey, Westport, Connecticut, 2000, pp. 270.

[13] J. Gidley, G. Hampson, Integral Perspectives on School Educational Futures, in: S. Inayatullah, M. Bussey, I. Milojevic (Eds.), Alternative Educational Futures: Pedagogies for Emergent Worlds, Sense Publishers, Rotterdam, Netherlands, 2008.

[14] J. Gidley, 'Education for All' or Education for Wisdom?, in: M. Jain (Ed.), Unfolding Learning Societies: Deepening the Dialogues, Shikshantar, Udaipur, 2001.

[15] J. Gidley, Globalization and its Impact on Youth, Journal of Futures Studies, 6 (2001) 89106.

[16] J. Gidley, The metaphors of globalisation: A multi-layered analysis of global youth culture, in: S. Inayatullah (Ed.), The causal layered analysis (CLA) reader: Theory and case studies of an integrative and transformative methodology, Tamkang University, Taipei, 2004. [17] J. Gidley, Spiritual epistemologies and integral cosmologies: Transforming thinking and culture, in: S. Awbrey, D. Dana, V. Miller, P. Robinson, M.M. Ryan, D.K. Scott (Eds.), Integrative Learning and Action: A Call to Wholeness, Peter Lang Publishing, New York, 2006, pp. 29-55.

[18] J. Gidley, Educational Imperatives of the Evolution of Consciousness: The Integral Visions of Rudolf Steiner and Ken Wilber, International Journal of Children's Spirituality, 12 (2007) 117-135.

[19] J. Gidley, The Evolution of Consciousness as a Planetary Imperative: An Integration of Integral Views, Integral Review: A Transdisciplinary and Transcultural Journal for New Thought, Research and Praxis, 5 (2007) 4-226.

[20] K. Wilber, Up from Eden: A Transpersonal View of Human Evolution (2nd ed.), Quest Books, Wheaton, IL, 1981/1996.

[21] K. Wilber, The Atman Project: A Transpersonal View of Human Development (2nd ed.), Quest Books, Wheaton, IL, 1980/1996.

[22] K. Wilber, The Marriage of Sense and Soul: Integrating Science and Religion, Hill of Content, Melbourne, 1998.

[23] K. Wilber, Integral Psychology: Consciousness, Spirit, Psychology, Therapy, Shambhala, Boston, 2000.

[24] K. Wilber, A Theory of Everything: An Integral Vision for Business, Politics, Science and Spirituality, Shambhala, Boulder, 2000.

[25] K. Wilber, Sex, Ecology, Spirituality: The spirit of evolution (2nd ed., revised). Shambhala, Boston, 1995/2000.

[26] K. Wilber, The Eye of Spirit: An Integral Vision for a World Gone Slightly Mad, Shambhala, Boston, 2001.

[27] J. Gebser, The Ever-Present Origin, Ohio University Press, Athens, Ohio, 1949/1985.

[28] S. Aurobindo, The Life Divine. 2nd American Edition. (Originally published in the monthly review Arya 1914-1920), Lotus Press, Twin Lakes, WI, 1914/2000.

[29] R. Benedikter, Postmodern spirituality: A dialogue in five parts, in, International Civic Society Initiative for the UN Decade Education for Sustainable Development (2005-2014), Innsbruck, 2005. 
[30] R. Steiner, The Evolution of Consciousness as Revealed through Initiation Knowledge (GA 227) (2nd ed.) (V. E. W. \& C. D., Trans.). [13 Lectures: Penmaenmawr, N. Wales, August 19 - 31, 1923] (Original published work 1926), Rudolf Steiner Press, London, 1926/1966.

[31] W.I. Thompson, Coming into Being: Artifacts and Texts in the Evolution of Consciousness, MacMillan Press Ltd, London, 1998.

[32] J. Wade, Changes of Mind: A Holonomic Theory of the Evolution of Consciousness, SUNY Press, New York, 1996.

[33] P. Russell, The Global Brain Awakens: Our Next Evolutionary Step, Element Books, Melbourne, 2000.

[34] M. Donald, A Mind so Rare: The Evolution of Human Consciousness W. W. Norton and Company, New York, 2001.

[35] D. Elgin, Global Consciousness Change: Indicators or an Emerging Paradigm, in, The Millennium Project, San Anselmo, CA, 1997.

[36] T. Hart, From Information to Transformation: Education for the Evolution of Consciousness, Peter Lang, New York, 2001.

[37] A. Gangadean, A Planetary Crisis of Consciousness: From Ego-based Cultures to a Sustainable Global World in: Kosmos: An Integral Approach to Global Awakening 2006, pp. 37-39.

[38] E. László, Quantum shift in the global brain: How the new scientific reality can change us and our world, Inner Traditions, Rochester, Vermont, 2008.

[39] B. Swimme, The Universe Story: From the Primordial Flaring Forth to the Ecozoic Era Celebration of the Unfolding Cosmos, HarperCollins Publishers, New York, 1992.

[40] D. Loye, Darwin's Lost Theory of Love: A Healing Vision for the New Century, iUniverse Inc, Lincoln, NE, 1998.

[41] D. Loye, The Great Adventure: Toward a Fully Human Theory of Evolution, in: R.D. Mann (Ed.) SUNY Series in Transpersonal and Humanistic SUNY Press, Albany, 2004. [42] J.D. Sinnott, The Dance of the Transforming Self: Both Feelings of Connection and Complex Thought are Needed for Learning, New Directions for Adult and Continuing Education, 108 (2005) 27-37.

[43] M. Commons, C. Armon, L. Kohlberg, F. Richards, A, T.A. Grotzer, J.D. Sinnott, Adult Development, Volume 2: Models and Methods in the Study of Adolescent and Adult Thought, in, Praeger, Westport, CT, 1990.

[44] L. Kohlberg, Which Postformal Stages are Stages?, in: M. Commons, C. Armon, L. Kohlberg, F. Richards, A, T.A. Grotzer, J.D. Sinnott (Eds.), Adult Development, Volume 2: Models and Methods in the Study of Adolescent and Adult Thought, Praeger, Westport, CT, 1990.

[45] J.D. Sinnott, The Development of Logic in Adulthood: Postformal Thought and its Applications, Springer, New York, 1998.

[46] G. Labouvie-Vief, Wisdom as Integrated Thought: Historical and Developmental Perspectives, in: R. Sternberg, J., C.A. Berg (Eds.), Wisdom: its Nature, Origins, and Development, Cambridge University Press, Cambridge, 1992.

[47] M.L. Commons, F. Richards, A, Organizing Components into Combination: How Stage Transition Works, Journal of Adult Development, 9 (2002) 159-177.

[48] W.R. Torbert, Action Inquiry: The Secret of Timely and Transforming Leadership, Berrett-Koehler Publishers, San Francisco, CA, 2004.

[49] C. Cowan, C., N. Todorovic, Dr. Clare W. Graves Explores Human Nature: The Never Ending Quest: A treatise on an emergent cyclical conception of adult behavioural systems and their development, ECLET Publishing Santa Barbara, 2005. 
[50] C. Bassett, Wisdom in three acts: Using transformative learning to teach for wisdom [Electronic version], in: Sixth International Transformative Learning Conference, East Lansing, Michigan, 2005.

[51] R. Benedikter, Global systemic shift: The "three ends" of our epoch and their perspective in the interplay between the four system spheres economics, politics, culture and religion, in: James Martin Advanced Research Seminar Programme, Oxford University, 2007.

[52] J. Earley, Transforming Human Culture: Social Evolution and the Planetary Crisis, SUNY Press, New York, 1997.

[53] E. László, The Chaos Point: The World at the Crossroads, Hampton Roads Publishing Company, Inc., Charlottsville, VA, 2006.

[54] A. Montuori, Planetary culture and the crisis of the future, World Futures: the Journal of General Evolution, 54 (1999) 232-254.

[55] E. Morin, A.B. Kern, Homeland Earth: A Manifesto for the New Millennium (Translated Sean Kelly, Roger Lapoint Hampton Press, Cresskill, NJ, 1999.

[56] B. Nicolescu, Manifesto of Transdisciplinarity (Translated by Karen-Claire Voss), SUNY Press, New York, 2002.

[57] B. Swimme, M.E. Tucker, The Evolutionary Context of an Emerging Planetary

Civilization, in: Kosmos: An Integral Approach to Global Awakening, 2006, pp. 7-8.

[58] L.v. Bertalanffy, General Systems Theory: Foundations, Development, Applications

(Revised Edition), George Braziller, Inc., New York, 1969/1976.

[59] A. Combs, The Radiance of Being: Understanding the Grand Integral Vision: Living the Integral Life, Paragon House, St. Paul, 2002.

[60] A. Einstein, Relativity: The Special and General Theory (Translated Robert W. Lawson), in, Bartelby.com, 1920/2000.

[61] H. Maturana, F. Varela, Autopoiesis and Cognition: The Realization of the Living, Springer, New York, 1980/1991.

[62] P. Cicovacki, Transdisciplinarity as an interactive method: A critical reflection on the three pillars of transdisciplinarity [Electronic version], in: Das Verbindende der Kulturen, The Unifying Aspects of Cultures, Les points communs des cultures, Research Institute for Regional and Transnational Processes (INST), Vienna, Austria, 2004.

[63] H. Bergson, Creative Evolution (A. Mitchell, Trans.), Macmillan \& Co., New York, 1911/1944.

[64] G. Deleuze, F. Guattari, What is Philosophy? (First published in French 1991)

(Translated by Hugh Tomlinson and Graham Burchell, Columbia University Press, New York, 1994.

[65] R. Steiner, The Philosophy of Freedom: The basis for a modern world conception (GA 4)

(M. Wilson, Trans.) (Rev. ed.). (Original work published 1894) The Anthroposophic Press, Spring Valley, NY, 1894/1964.

[66] A.N. Whitehead, Process and Reality, Free Press, New York, 1929/1985.

[67] A. Gangadean, Between worlds: The emergence of global reason, Peter Lang, New York, 1998.

[68] G.P. Hampson, Integral reviews postmodernism: The way out is through Integral Review: A Transdisciplinary and Transcultural Journal for New Thought, Research and Praxis 4(2007) 108-173.

[69] E. László, Science and the Akashic Field: An Integral Theory of Everything, Inner Traditions, Rochester, Vermont, 2007.

[70] G. Deleuze, Difference and Repetition (First published in French 1968), Columbia University Press, New York, 1968/1994.

[71] G. Deleuze, T. Conley, The Fold: Leibniz and the Baroque, University of Minnesota Press, Minneapolis, 1992. 
[72] J. Derrida, Of Grammatology, The John Hopkins University Press, Baltimore, Maryland, 1998.

[73] J. Derrida, Structure, Sign, and Play in the Discourse of the Human Sciences [Electronic version], in: Writing and Difference, Routledge, London, 2001, pp. 278-294.

[74] J. Kristeva, The Kristeva Reader Columbia University Press, New York, 1986.

[75] H. Cixous, The Laugh of the Medusa, in: R. Warhol, D. Price Herndl (Eds.), Feminisms: An Anthology of Literary Theory and Criticism, Rutgers University Press, Piscataway, NJ, 1991.

[76] M. Foucault, The Order of Things: An Archaeology of the Human Sciences (Original published in 1966), Vintage Books, New York, 1966/1994.

[77] M. Foucault, Text/Context of Other Space, Diacritics, 16 (1986) 22-27.

[78] J. Habermas, A Review of Gadamer's Truth and Method, in: B.R. Wachterhauser (Ed.), Hermeneutics and Modern Philosophy, SUNY Press, Albany, 1986, pp. 243-276.

[79] H.-G. Gadamer, Truth and Method (Translated by Weinsheimer, J and Marshal, D, New York) Second Revised Edition Continuum International Publishing Group, London, 1960/2005.

[80] H.-G. Gadamer, Text and Interpretation, in: B.R. Wachterhauser (Ed.), Hermeneutics and Modern Philosophy, State University of New York Press, Albany, 1986, pp. 377-396.

[81] M. Heidegger, Being and Time (Translated John Macquarie and Edward Robinson), Blackwell, Oxford, 1927/1962.

[82] P. Ricoeur, Time and Narrative (Translated Kathleen Blamey and David Pellauer), University of Chicago Press, Chicago, 1985/1988.

[83] P. Ricoeur, Hermeneutics and the Critique of Ideology, in: B.R. Wachterhauser (Ed.), Hermeneutics and Modern Philosophy, State University of New York Press, New York, 1986, pp. 300-339.

[84] J. Baudrillard, Jean Baudrillard: Selected writings, Stanford University Press, Palo Alto, CA, 1988.

[85] M.B. Steger, The rise of the global imaginary: Political ideologies from the French revolution to the global war on terror, Oxford University Press, Oxford, 2008.

[86] S. Marginson, Competition and Markets in Higher Education: A 'glonacal' analysis, Policy Futures in Education, 2 (2004) 175-244.

[87] L. Grigg, R. Johnston, N. Milson, Emerging Issues for Cross-Disciplinary Research: Conceptual and Empirical Dimensions, in, DEST, Commonwealth of Australia, Canberra, 2003.

[88] J.T. Klein, Prospects for Transdisciplinarity, Futures, 36 (2004) 515-526.

[89] P. Ricoeur, The Rule of Metaphor: Multidisciplinary Studies of the Creation of Meaning in Language (Translated by Czerny, R), University of Toronto Press, Toronto, 1997.

[90] P. van den Besselaar, G. Heimeriks, Disciplinary, Multidisciplinary, Interdisciplinary:

Concepts and Indicators, in: 8th Conference on Scientometrics and Informetrics, Sydney, Australia, 2001.

[91] J. Habermas, Between naturalism and religion: Philosophical essays, Polity Press, London, 2008.

[92] J.P. Manoussakis, After God: Richard Kearney and the Religious Turn in Continental Philosophy, Fordham University Press, New York, 2006.

[93] J.D. Caputo, The prayers and tears of Jacques Derrida: Religion without religion Indiana University Press, Bloomington and Indianopolis, 1997.

[94] J. Gidley, Globally Scanning Megatrends of the Mind: Potential Futures of "Futures Thinking", Futures: The journal of policy, planning and futures studies, 42 (2010) 1040-1048. [95] J. Gidley, Educating for evolving consciousness: Voicing the emergenc-y for love, life and wisdom, in, The International Handbook of Education for Spirituality, Care and Wellbeing, Springer, New York, 2009. 
[96] J. Gidley, Unveiling the Human Face of University Futures, in: S. Inayatullah, J. Gidley (Eds.), The University in Transformation: Global Perspectives on the Futures of the University, Bergin and Garvey, Westport, CT, 2000, pp. 235-245.

[97] J. Gidley, Evolving Higher Education Integrally: Delicate Mandalic Theorising, in: S. Esbjörn-Hargens, O. Gunnlaugson, J. Reams (Eds.), Integral Education: New Directions for Higher Learning, State University of New York Press, New York, 2010, pp. 345-361.

[98] B. Dahlin, Education, history and be(com)ing human: Two essays in philosophy and education, in, Karlstad University Karlstad, 2006.

[99] F. Schiller, On The Aesthetic Education of Man - in a series of letters (First published in 1795), Frederick Ungar Publishing, New York, 1954/1977.

[100] J.T. Klein, A platform for a shared discourse of interdisciplinary education [Electronic version], in: Journal of Social Science Education, 2006.

[101] H. Holborn, A History of Modern Germany, 1648-1840, Princeton University Press, Princeton, 1964.

[102] J. Dator, The Futures for Higher Education: From Bricks to Bytes to Fare Thee Well!, in: S. Inayatullah, J. Gidley (Eds.), The University in Transformation: Global Perspectives on the Futures of the University, Bergin \& Garvey, Westport, CT, 2000.

[103] J.J. Scheurich, K.B. McKenzie, Foucault's Methodologies: Archaeology and Genealogy, in: N. Denzin, Y. Lincoln (Eds.), The Sage Handbook of Qualitative Research, (3rd ed.), Sage Publications, Thousand Oaks, CA, 2005, pp. 841-868.

[104] M. MacLure, The bone in the throat: Some uncertain thoughts on baroque method, International Journal of Qualitative Studies in Education, 19 (2006) 729-745.

[105] P. Abbs, Against the flow: The arts, postmodern culture and education, RoutledgeFalmer, London, 2003.

[106] C.L.S. Coryn, D.C. Schröter, M. Scriven, A Call to Action: The First International Congress of Qualitative Inquiry, Journal of MultiDisciplinary Evaluation 3(2005) 155-165.

[107] N. Denzin, The First International Congress of Qualitative Inquiry, Qualitative Social Work, 4 (2005) 1105-1111.

[108] J. Holt, How Children Learn, Pelican, Harmondsworth, Middlesex, 1970.

[109] J. Miller, P., Education and the Soul: Towards a Spiritual Curriculum, State University of New York Press, Albany, NY, 2000.

[110] R. Miller, What Are Schools For? Holistic education in American culture, Holistic Education Press, Brandon, Vermont, 1990.

[111] R. Miller, Holistic Education for an Emerging Culture, in: S. Glazer (Ed.), The Heart of Learning: Spirituality in Education, Putnam, New York, 1999.

[112] R. Slaughter, What is Futures Education?, in: R. Slaughter (Ed.), Studying the Future: an Introductory Reader, Commission for the future, Bicentennial futures education project, Melbourne, 1989, pp. 10-20.

[113] N. Gough, Seven principles for exploring futures in the curriculum, in: R. Slaughter (Ed.), Studying the Future: An Introductory Reader, Commission for the Future, Bicentennial Futures Education Project, Melbourne, 1989, pp. 51-59.

[114] M. Rogers, Student Responses to Learning about the Future, in: D. Hicks, R. Slaughter (Eds.), World Yearbook of Education 1998: Futures Education, Kogan Page, London, 1998.

[115] D. Hicks, Identifying Sources of Hope in Post-modern Times, in: D. Hicks, R. Slaughter (Eds.), World Yearbook of Education 1998: Futures Education, Kogan Page, London, 1998. [116] J. Fien, Environmental Education for a New Century, in: D. Hicks, R. Slaughter (Eds.), World Yearbook 1998: Futures Education, Kogan Page, London, 1998.

[117] J. Gidley, Youth Futures: Transcending Violence through the Artistic Imagination, in: S. Inayatullah, P. Wildman (Eds.), Futures Studies: Methods, Emerging Issues and Civilizational Visions. A Multi-Media CD ROM, Prosperity Press, Brisbane, 1998.

[118] H. Read, Education through Art, Faber and Faber, London, 1943. 
[119] K. Rose, J. Kincheloe, Art, Culture and Education: Artful Teaching in a Fractured Landscape, Peter Lang, New York, 2003.

[120] B. Davis, Inventions of teaching: A genealogy, Lawrence Erlbaum Associates, Mahwah, NJ, 2004.

[121] E. Morin, Seven Complex Lessons in Education for the Future, UNESCO, Paris, 2001.

[122] K. Egan, Romantic Understanding: The Development of Rationality and Imagination,

Ages 8-15, Routledge, London, 1990.

[123] K. Egan, The Educated Mind: How Cognitive Tools Shape our Understanding, The

University of Chicago Press, Chicago, 1997.

[124] T.W. Nielsen, Rudolf Steiner's Pedagogy of Imagination, Peter Lang, 2004.

[125] T.W. Nielsen, Towards a pedagogy of imagination: a phenomenological case study of

holistic education, Ethnography and Education, 1 (2006) 247-264.

[126] B. Neville, Educating Psyche: Emotion, Imagination, and the Unconscious in Learning, Collins Dove, Melbourne, 1989.

[127] D. Sloan, Imagination, Education and our Postmodern Possibilities, ReVision: A Journal of Consciousness and Transformation, 15 (1992) 42-53.

[128] J.T. Gatto, Dumbing us Down: The Hidden Curriculum of Compulsory Schooling, New Society, Philadelphia, 1992.

[129] H.A. Giroux, Border Crossing: Cultural Workers and the Politics of Education, Routledge, New York, 1992.

[130] M. Jain, V. Miller, S. Jain, Unfolding Learning Societies: Deepening the Dialogues, in: M. Jain (Ed.) Vimukt Shiksha, The People's Institute for Rethinking education and Development, Udaipur, Rajasthan, India, 2001.

[131] D.W. Jardine, To Dwell with a Boundless Heart: Essays in Curriculum Theory, Hermeneutics, and the Ecological Imagination, Peter Lang Publishing, New York, 1998. [132] D. Orr, Earth in Mind: On Education, Environment, and the Human Prospect, Island Press, Washington D.C, 1994.

[133] D. Hicks, Lessons for the Future, Routledge, London, 2002.

[134] I. Milojevic, Educational Futures: Dominant and Contesting Visions Routledge, London, 2005.

[135] R. Slaughter, From rhetoric to reality: The emergence of futures into the educational mainstream, in: J. Gidley, S. Inayatullah (Eds.), Youth Futures: Comparative Research and Transformative Visions, Praeger, Westport, 2002, pp. 175-186.

[136] S.H. Forbes, Holistic Education: An Analysis of its Ideas and Nature, Solomon Press/Foundation for Educational Renewal, Brandon, VT, 2003.

[137] T. Hart, Teaching for Wisdom, Encounter: Education for Meaning and Social Justice, 14 (2001) 3-16.

[138] R. Miller, Making Connections to the World: Some Thoughts on Holistic Curriculum [Electronic version], in: Encounter: Education for Meaning and Social Justice, 2006.

[139] R.G. Nava, Holistic Education: Pedagogy of Universal Love, Holistic Education Press, Brandon, VT, 2001.

[140] P. Palmer, The Courage to Teach, Jossey-Bass, San Francisco, 1998.

[141] M.C. Bronson, A. Gangadean, ((Circling)) the /square/: Reframing integral education discourse through deep dialogue, ReVision, 28 (2006) 36-48.

[142] S. Stack, Integrating science and soul in education: The lived experience of a science educator bringing holistic and Integral perspectives to the transformation of science teaching, in, Curtin University of Technology, Perth, Western Australia, 2006.

[143] A. Adams, Education: From conception to graduation. A systemic, integral approach, in, California Institute of Integral Studies, California, 2006.

[144] E. Boulding, Building a Global Civic Culture: Education for an Interdependent World, Syracuse University Press, 1990. 
[145] S. Goerner, Rethinking Education in the Light of Great Change, New Horizons for Learning (2000).

[146] J. Visser, Rethinking Learning: Implications for Policy, Research and Practice, in: M. Jain (Ed.), Unfolding Learning Societies: Challenges and Opportunities, Shikshantar: The People's Institute for Rethinking Education and Development, Udaipur, 2000.

[147] R. Horn, Post-formal design conversation: designing just and caring educational systems, Systems Research and Behavioural Sciences, 18 (2001) 361-371.

[148] J. Kincheloe, S. Steinberg, P.H. Hinchey, The post-formal reader: Cognition and education in: S. Steinberg, J. Kincheloe (Eds.) Critical Education Practice, Falmer Press, New York, 1999.

[149] D. Elkind, Waldorf Education in the Postmodern World, Renewal: A Journal for Waldorf Education, 6 (1997) 5-9.

[150] D. Elkind, Schooling the Postmodern Child, Research Bulletin, 3 (1998).

[151] M. Peters, Naming the Multiple: Poststructuralism and Education, in: H.A. Giroux (Ed.)

Critical Studies in Education and Culture Series, Bergin \& Garvey, Westport, CT, 1998.

[152] J. Gidley, From Crisis to Confidence: The Development of Social and Emotional

Education in Australia, in: C. Clouder (Ed.), Social and Emotional Education: International

Analysis II, Fundacione Marcelino Botin, Santander, 2011.

[153] M. Chater, Just another Brick in the Wall: Education as Violence to the Spirit, International Journal of Children's Spirituality, 11 (2006) 47-56.

[154] M. de Souza, Educating for Hope, Compassion and Meaning in a Divisive and Intolerant World, International Journal of Children's Spirituality, 11 (2006) 165-175.

[155] S. Glazer, The Heart of Learning: Spirituality in Education, in, Jeremy P. Tarcher /

Putnam, New York, 1994.

[156] J. Pridmore, 'Dancing cannot start too soon': Spiritual Education in the Thought of Jean Paul Friedrich Richter, International Journal of Children's Spirituality, 9 (2004) 279-291.

[157] G. Woods, M. O'Neill, P.A. Woods, Spiritual Values in Education: Lessons from

Steiner, The International Journal of Children's Spirituality, 2 (1997) 25-40.

[158] W. Daniels, Can educators transform the educational system: A Foucauldian archeological gaze into transformative education, in, The University of Texas at Austin, Texas, 2002.

[159] P.K. Arlin, The Wise Teacher: A Developmental Model of Teaching Theory into Practice, 38 (1999) 12-17.

[160] J.G. Henderson, K.R. Kesson, Curriculum Wisdom: Educational Decisions in Democratic Societies, Pearson Education Inc., Upper Saddle River, NJ, 2004.

[161] R. Sternberg, J., Why Schools Should Teach for Wisdom: The Balance Theory of Wisdom in Educational Settings, Educational psychologist, 36 (2001) 227-245.

[162] R. McDermott, An Emersonian Approach to Higher Education, ReVision: A Journal of Consciousness and Transformation, 28 (2005) 6-17.

\footnotetext{
${ }^{\mathrm{i}}$ Although this quote is well known, oft-cited, and always attributed to Einstein, I have not been able-in spite of numerous searches - to uncover its source.

ii The first Integral Institute to be founded in the USA was the California Institute of Integral Studies, which was originally based on the teachings of Sri Aurobindo.

iii The strongest concentration of academic work based on Wilberian Integral Theory is at John F. Kennedy

University, California.
} 